\title{
KEJADIAN PNEUMONIA PADA BALITA DI WILAYAH KERJA PUSKESMAS RUMBAI KOTA PEKANBARU DAN FAKTOR YANG BERHUBUNGAN
}

\author{
NURVI SUSANTI DAN ZULMELIZA RASYID* \\ *Dosen Prodi IKM Stikes Hangtuah Pekanbaru
}

\begin{abstract}
Accordingon the profile of the health of Riau Provincein 2011, Case Detection Rate (CDR) is still below the national target of 70\%. Whereas the achievement of these national targets are $90 \%$ out of 100\%. Toddler's pneumonia sufferers were estimated at as much as 10.940 Riau Province sufferers or 1704 invention of pneumonia cases (15.6 percent), while cases of toddler's pneumonia who prevail in Rumbai Health Center 82.4\%. Thus pneumonia is still a health problem because it can cause a rapid death if not treated promptly. This research goalsto find out the prevalence of toodler's pneumonia incidence as well as knowing the gender relations, knowledge of mother, mother's education, mother's work status, $B B L R$, immunization status, exclusive breast feeding, housing density, and the role of health workers by number incidence of pneumonia in rumbai health centerpekanbaru city work area.The research is using quantitative analysis with the design case control.Population consist ofpopulationcases and population control.Sample case was 98 toddlers' whos suffer from toddler's pneumoniain rumbai health centerpekanbaru city work area.The sampling technique is using simple random sampling, and data anlysis are univariat, bivariat, and multivariat, with logistic regression test. The research resultsshowed that all variables (9 variables has significancy with pneumonia toddlers, which are sex OR 4,304 (CI $95 \%$ : 2,36-7,85), education OR 4,267 (CI $95 \%$ 2,34-7,75 ), work OR 0,516 (CI $95 \%$ 0,28-0,92 ), knowledge OR 1,947 (CI $95 \%$ 1,10-3,44 ), BBLROR 4,002 (CI $95 \%$ 2,16 -7,39) , immunization status OR 20,938 (CI $95 \%$ 9,55-45,49 , exclusive breast feeding OR 4,500 (CI 90 \% 2,46-8,21 ), housing densityOR 2,212 (CI $95 \%$ 1,22-3,95 ), the role of health workers OR 1,947 (CI 95 \% 1,103,44 ). Multivariate analysis showed variable most dominant were immunization status with $p$ value $=0.0001$ OR $95 \%$ CI 13,582 (5,590-33,004)). Conclusions,It is necessary to spread information and sendhealth promotion team to hold health counseling to women who had pneumonia toddlers particularly on penumonia disease.
\end{abstract}

\section{PENDAHULUAN}

Pneumonia adalah infeksi akut yang menyerang jaringan paru-paru (alveoli) yang disebabkan oleh bakteri, virus maupun jamur. Terjadinya pneumonia pada anak balita seringkali bersamaan dengan terjadinya proses infeksi akut pada bronkus yang disebut bronchopneumonia. Gejala penyakit pneumonia ini berupa nafas cepat dan nafas sesak, karena paru meradang secara mendadak. Batas nafas cepat adalah frekuensi pernafasan sebanyak 60 kali per menit atau lebih pada umur balita $<2$ bulan, 50 kali per menit atau lebih pada anak usia 2 bulan sampai kurang dari 1 tahun, dan 40 kali per menit atau lebih pada anak usia 1 tahun sampai kurang dari 5 tahun. Pneumonia yang menyerang 
bayi dan balita bisa menyebabkan kematian yang cepat bila tidak segera diobati (Kemenkes, 2010).

Diperkirakan 70 \% kematian anak balita akibat pneumonia di seluruh dunia terjadi di negara berkembang, terutama Afrika dan Asia Tenggara dengan angka kematian balita di atas 49 per 1000 kelahiran hidup (15- $20 \%$ ), distribusi penyebab kematian pada anak balita sebesar 22\% diantaranya disebabkan oleh pneumonia (WHO, 2011).

Pneumonia menduduki peringkat kedua penyebab kematian bayi $(12,3 \%)$ dan balita (13,2\%) setelah diare (Kemenkes RI, 2010). Pneumonia termasuk dalam sepuluh penyakit terbanyak penyakit rawat inap di rumah sakit tahun 2010 (Ditjen Bina Upaya Kesehatan, Kemenkes RI, 2012).

Di Provinsi Riau, Case Detection Rate (CDR) tahun 2011 masih di bawah target nasional yaitu $87 \%$ Penderita pneumonia anak balita di Prov. Riau sebanyak 66.806 penderita atau 8651 kasus pneumonia (13\%).Pneumonia di Kabupaten Kampar menduduki urutan ketiga terbanyak dengan jumlah penderita sebanyak 7081 atau 717 kasus pneumonia ( 10,1\%) ( Profil Dinkes Prov. Riau, 2011).

Faktor-faktor yang berhubungan dengan kejadian pneumonia anak balita antara lain : karakteristik ibu (pendidikan ibu, pengetahuan ibu tentang pneumonia, pekerjaan ibu), faktor pada anak balita (pemberian ASI eksklusif, status imunisasi anak balita, status gizi anak balita, (BBLR dan jenis kelamin anak balita), faktor lingkungan (kepadatan hunian, pencemaran udara dalam rumah, jarak ke fasilitas kesehatan) (Depkes RI, 2008).

Berdasarkan laporan Dinas

Kesehatan Kota Pekanbaru tahun 2012diperoleh bahwa dari 20 puskesmas yang ada di kota Pekanbaru, Salah satunya adalah Puskesmas Rumbai dengan jumlah balita pada tahun 2012 sebanyak $4327 \quad$ sedangkan jumlahpenderita pneumonia balita di Puskesmas Rumbai pada tahun pada tahun 2012 sebanyak 357 kasus. Sedangkan target pencapaian Nasional yaitu 90\% dari 100\% balita(Profil Dinkes Kota Pekanbaru, pemegang P2 ISPA, 2013).

Berdasarkan dari data di atas, maka perlu untuk melakukan penelitian pneumonia pada anak balita di Wilayah Kerja Puskesmas Rumbai. Penelitian ini bertujuan untuk mengetahui faktor-faktor yang berhubungan dengan terjadinya pneumonia pada anak balita tersebut, seperti faktor jenis Kelamin, pendidikan ibu, pekerjaan ibu, pengetahuan ibu, BBLR, status imunisasi, pemberian ASI eksklusif, kepadatan hunian dan peran petugas kesehatan.

\section{METODE PENELITIAN}

Penelitian ini bersifat kuantitatif analitik observasional dengan jenis desain studi kasus kontrol.Sampel kasus adalah sebahagian ibu yang mempunyai anak balita yang menderita pneumonia sedangkan sampel kontrol adalah sebahagian ibu yang mempunyai anak balita yang tidak menderita pneumonia

Populasi dalam penelitian ini adalah semua anak balita yang tercatat pada data rekam medic di Wilayah Kerja Puskesmas Rumbai Kecamatan Rumbai Pesisir Kota Pekanbaru, selama bulan Juli sampai dengan September 2014 sebayak 357 balita. Sampel dalam penelitian ini terdiri dari sampel kasus dan sampel kontrol. Sampel kasus adalah sebagian anak balita yang menderita pneumonia yang tercatat pada data rekam medik di Wilayah Kerja Puskesmas Rumbai Kecamatan Rumbai Pesisir Kota 
Pekanbaru Sampel kontrol adalah sebahagian ibu yang mempunyai anak balita yang tidak menderita pneumonia. Adapun kriteria sampel meliputi Kriteria inklusi yaitu Ibu yang mempunyai Anak balita penderita pneumonia dan berada di Wilayah Kerja Puskesmas Rumbai Kecamatan Rumbai Pesisir Kota Pekanbaru. Dan kriteria eksklusi adalah ibu balita penderita pneumonia tidak berada ditempat sewaktu kunjungan tiga kali berturut-turut. Pengumpulan data dalam penelitian ini menggunakan data primer meliputi data jenis kelamin, pengetahuan ibu, pendidikan ibu, pekerjaan ibu, BBLR, status imunisasi, pemberian ASI eksklusif, kepadatan hunian dan peran petugas kesehatan.Data diperoleh melalui wawancara menggunakan kuesioner.Data sekunder meliputi data Profil Dinkesehatn Kota Pekanbaru, demografi wilayah penelitian serta data rekam medik diPuskesmas Rumbai dan Profil Kesehatan Puskesmas Rumbai.
Cara memperoleh data dalam penelitian ini adalah dengan mencatat data pneumonia anak balita dan bukan pneumoniadari statusrekam medik di Wilayah Kerja Puskesmas Rumbai Kecamatan Rumbai Pesisir Kota Pekanbaru. Analisa data dilakukan secara bertahap yang meliputi analisis univariat, bivariat dilakukan dengan uji chi-square dan multivariat dengan uji regresi logistik ganda.

\section{HASIL}

Penelitian dilaksanakan di Wilayah Kerja Puskesmas Rumbai Kecamatan Rumbai Pesisir Kota Pekanbaru, tabel 1 menunjukkan hasil univariat yaitu diperoleh mayoritasresponden bekerja $(62,8 \%)$, berpendidikan rendah $(52,0)$, berjenis kelamin laki-laki (54,1 \%), berpengetahuan rendah (55,1\%), BBLR(60,7\%), status imunisasi tidak lengkap (59,7\%), tidak memberikan asi eksklusif (53,6\%), padat hunian (62,2\%) dan petugas kesehatan tidak berperan (70,4\%). 
Tabel 1

Distribusi frekuensi jenis kelamin, pengetahuan ibu, pendidikan ibu, pekerjaan ibu, BBLR, status imunisasi, pemberian ASI eksklusif, kepadatan hunian dan peran petugas kesehatan yang dihipotesiskan berhubungan dengan Kejadian Pneumonia

Balita Di Wilayah kerja Puskesmas Rumbai

Kecamatan Rumbai Pesisir Kota Pekanbaru

\begin{tabular}{|c|c|c|}
\hline Variabel & Frekuensi & Persentase (\%) \\
\hline \multicolumn{3}{|l|}{ Jenis Kelamin } \\
\hline Laki-Laki & 106 & 54.1 \\
\hline Perempuan & 90 & 45.9 \\
\hline \multicolumn{3}{|l|}{ Pendidikan Ibu } \\
\hline Rendah & 102 & 52.0 \\
\hline Tinggi & 94 & 48.0 \\
\hline \multicolumn{3}{|l|}{ Pekerjaan Ibu } \\
\hline Bekerja & 123 & 62.8 \\
\hline Tidak Bekerja & 73 & 37.2 \\
\hline \multicolumn{3}{|l|}{ Pengetahuan Ibu } \\
\hline Rendah & 108 & 55.1 \\
\hline Tinggi & 88 & 44.9 \\
\hline \multicolumn{3}{|l|}{ BBLR } \\
\hline BBLR & 119 & 60.7 \\
\hline Normal & 77 & 39.3 \\
\hline \multicolumn{3}{|c|}{ Status Imunisasi Balita } \\
\hline Tidak lengkap & 117 & 59.7 \\
\hline Lengkap & 79 & 40.3 \\
\hline \multicolumn{3}{|c|}{ Pemberian ASI Eksklusif } \\
\hline Tidak Eksklusif & 105 & 53.6 \\
\hline Eksklusif & 91 & 46.4 \\
\hline \multicolumn{3}{|c|}{ Kepadatan Hunian } \\
\hline Padat & 122 & 62.2 \\
\hline Tidak Padat & 74 & 37.8 \\
\hline \multicolumn{3}{|c|}{ Peran Petugas Kesehatan } \\
\hline Tidak berperan & 138 & 70.4 \\
\hline Berperan & 58 & 29.6 \\
\hline
\end{tabular}

Tabel 2 menunjukkan hasil uji bivariat yaitu ada 9 (sembilan) variabel independen yang berhubungan signifikan dengan kejadian pneumonia balita, balita dengan jenis kelamin laki-laki lebih berisiko menderita pneumonia (C.I.95\% : $\mathrm{OR}=2,31-7,85$ ) dibanding dengan balita jenis kelamin perempuan. balita dengan ibu yang berpendidikan rendah lebih 
berisiko menderita pneumonia (C.I. 95\%

-7,75) dibanding balita dengan ibu berpendidikan tinggi. balita dengan ibu yang bekerja lebih berisiko menderita pneumonia (C.I. 95\% : OR = 0,28-0,92) dibanding balita dengan ibu yang tidak bekerja. balita dengan ibu yang berpengetahuan rendah lebih berisiko menderita pneumonia (C.I. 95\% : OR $=1,10-3,44$ ) dibanding balita dengan ibu denggan pengetahuan yang tinggi, balita dengan BBLR lebih berisiko menderita pneumonia (C.I. 95\% : OR = 2,16-7,39) dibanding dengan balita dengan berat badan normal, BALITA dengan status imunisasi tidak lengkap lebih berisiko menderita pneumonia (C.I. 95\% : OR = 9,55-45,89) dibanding dengan balita
: OR $=2,34$ dengan imunisasi yang lengkap, balita yang tidak diberi ASI eksklusif lebih berisiko menderita pneumonia (C.I. 95\% $:$ OR $=2,46-8,28)$ dibanding dengan balita yang diberi ASI eksklusif, balita dengan kepadatan hunian yang padat lebih berisiko menderita pneumonia (C.I. 95\% : OR = 1,22-3,99) dibanding dengan balita dengan kepadatan hunian yang tidak padat, balita dengan pneumonia yang petugas kesehatan yang tidak berperan lebih berisikomenderita pneumonia (C.I. 95\% : OR = 3,41-15,30) dibanding dengan petugas kesehatan yang berperan 
Tabel 2

Faktor-faktor yang berhubungan dengan Kejadian Pneumonia Pada Anak Balita

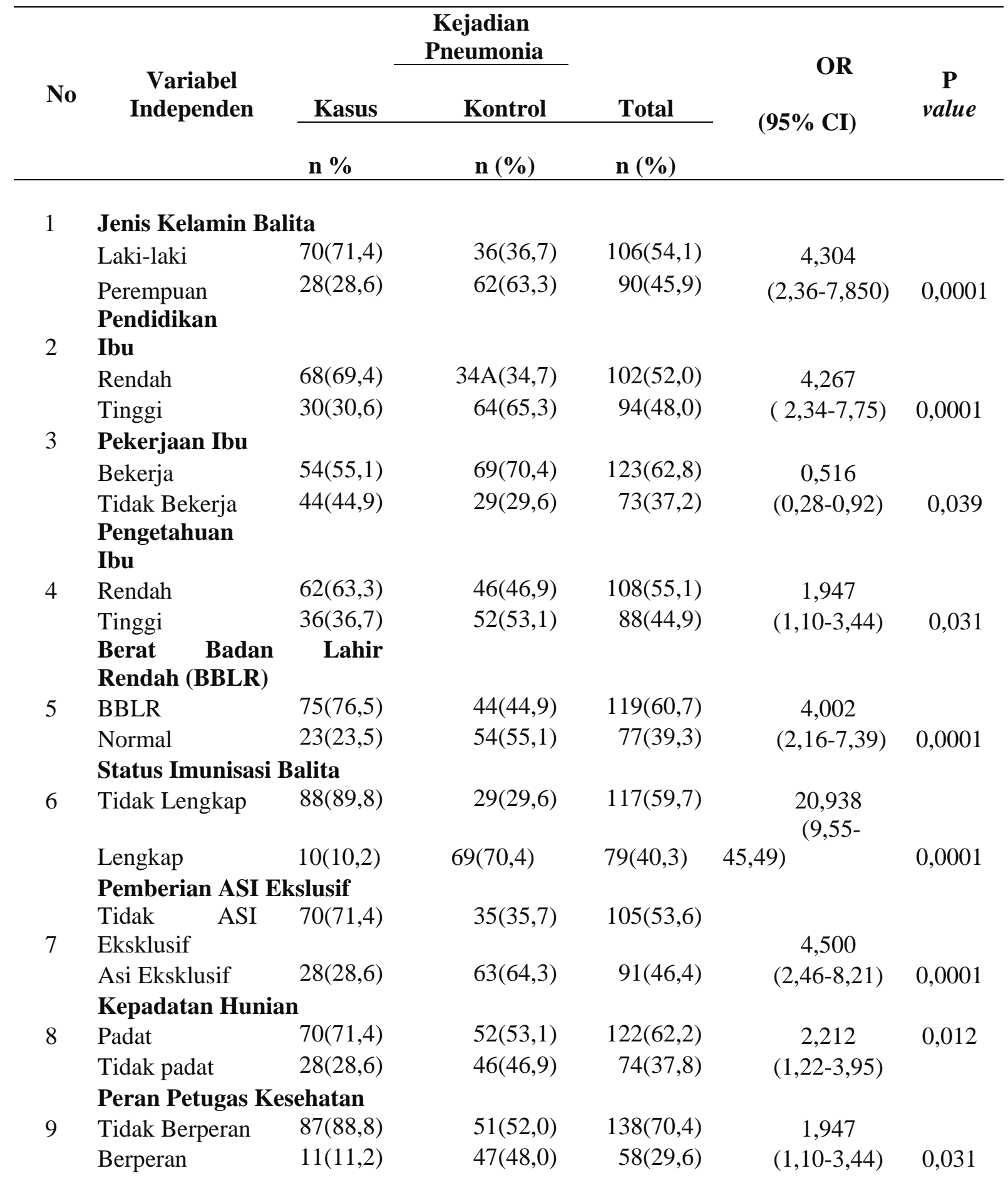


Tabel 3 menunjukkan Hasil multivariat dapat disimpulkan bahwa variabel yang berhubungan secara bermakna dengan kejadian pneumonia pada anak balita adalah berat badan lahir rendah (BBLR), status imunisasi anak balita, pemberian ASI eksklusif, status gizi anak balita, jenis kelamin anak balita, pendidikan ibu,pengetahuan ibu, padat hunian dan peran petugas kesehatan. Hasil analisis didapatkan bahwa variabel yang paling dominan berhubungan dengan kejadian pneumonia pada anak balita adalah status imunisasi balita dengan $\mathrm{OR}=13,5$ artinya balita dengan status imunisasi yang tidak lengkap lebih mempengaruhi kejadian pneumonia 13, 5 kali dibandingkan dengan status imunisasi lengkap.

Tabel 3

Pemodelan Multivariat Akhir (Model Akhir)

\begin{tabular}{llcccc}
\hline & & & \multicolumn{3}{c}{$\mathbf{9 5 \%}$ CI for EXB (B) } \\
\cline { 4 - 6 } No & Variabel Independen & P Value & $\begin{array}{c}\text { Exp } \\
\text { (B) }\end{array}$ & Lower & Upper \\
\hline 1 & BBLR & 0,022 & 2,770 & 1,156 & 6,635 \\
2 & Status Imunisasi & 0,0001 & 13,582 & 5,590 & 33,004 \\
3 & Pemberian ASI Eksklusif & 0,0001 & 7,311 & 2,907 & 18,390 \\
4 & Peran Petugas Kesehatan & 0,0001 & 8,868 & 3,154 & 24,935
\end{tabular}

\section{PEMBAHASAN}

\section{Hubungan Jenis Kelamindengan} Pneumonia anak balita

Dalam buku pedoman

pemberantasan penyakit ISPA untukpenanggulangan penumonia pada balita, balita jenis kelamin laki-laki memiliki risiko lebih besar untuk terkena pneumonia dibandingkan dengan balita jenis kelamin perempuan (Depkes, 2009).

Hasil penelitian Sari (2012), menyatakan bahwa balita jenis kelamin laki-laki berpeluang 1,740 kali untuk terjadinya pneumonia daribalita jenis kelamin perempuan.Dalam penelitian ini ditemukan bahwa jenis kelamin balita berhubungan sebab akibat Ibu adalah salah satu faktor yang secara tidak langsung mempengaruhi kejadian pneumonia pada balita.Tingkat pendidikan ibu yang rendah menyebabkan tindakan perawatan kepada balita yang tidak begitu baik, maka balita mudah terpapar kuman penyakit melalui dengan kejadian pneumonia balita. Jenis kelamin laki-laki lebih berpengaruhmenderita pneumonia dibandingkan dengan jenis kelamin perempuan. Kemungkinan laki-laki lebih banyak terpapar diluar rumah sehingga besar kemungkinan untuk terinfeksi kuman penyakit. Dalam buku pedoman pemberantasan penyakit ISPA untuk penanggulangan penumonia pada balita.Balita jenis kelamin laki-laki memiliki risiko lebih besar untuk terkena pneumonia dibandingkan dengan balita jenis kelamin perempuan (Depkes, 2009). HubunganPendidikan Ibu dengan Pneumonia anak balita

Pendidikan

saluran pernapasan sehingga terkena ISPA berlanjut menjadi pneumonia. Ibu dengan pendidikan yang lebih tinggi akan lebih banyak membawa anaknya untuk berobat ke fasilitas kesehatan, tetapi ibu dengan pendidikan rendah akan lebih 
memilih anaknya untuk berobat ke dukun atau mengobati sendiri (Sukar dalam Lindawati, 2010).

Hasil penelitian Hatta dalam Pamungkas (2012), menyebutkan bahwa balita yang ibunya berpendidikan rendah mempunyai risiko 2,037 kali lebih besar untuk terkena pneumonia dibandingkan dengan balita yang ibunya berpendidikan tinggi.

Hasil penelitian lainnya menyatakan bahwa balita dengan ibu yang berpendidikan rendah memiliki risiko 5,3 kali terkena pneumonia dibandingkan balita dengan ibu yang tingkat pendidikan tinggi (Fanada, 2012).

Tingkat pendidikan ibu yang rendah menyebabkan tindakan perawatan kepada balitan yang tidak begitu baik, maka balita mudah terpapar kuman penyakit melalui saluran pernapasan sehingga terkena ISPA berlanjut menjadi pneumonia.Kemungkinan ibu dengan pendidikan yang lebih tinggi akan lebih banyak membawa anaknya untuk berobat ke fasilitas kesehatan, tetapi ibu dengan pendidikan rendah akan lebih memilih balita untuk berobat ke dukun atau mengobati sendiri (Sukar dalam Lindawati, 2010).

Dalam penelitian ini ditemukan bahwa pendidikan ibu mempengaruhi kejadian pneumonia balita. Pendidikanrendah berpengaruh lebih besar menderita pneumonia dibandingkan dengan pendidikan tinggi pada ibu balita.

\section{Hubungan Pekerjaan Ibu dengan Pneumonia anak balita}

Pekerjaan ibu adalah suatu kegiatan atau aktivitas yang dilakukan seseorang ibu untuk memperoleh imbalan guna memenuhi kebutuhan hidupnya seharihari diluar rumah. Ibu balita yang bekerja diluar rumah akan kurang merawat balitanya karena sebagian waktunya tersita untuk bekerja sehingga kesehatan balitanya kurang diperhatikan dan rentan terhadap berbagai penyakit salah satunya penyakit pneumonia.

Menurut penelitian Pamungkas (2012), menyatakan bahwa ada hubungan pekerjaan ibu dengan kejadian pneumonia pada balita.Balita yang ibunya bekerja lebih berisiko menderita pneumonia dibandingkan dengan balita yang ibunya tidak bekerja. Balita yang dilahirkan dari ibu yang bekerja berisiko untuk menderita pneumonia 2,04 kali dibandingkan dengan balita yang dilahirkan dari ibu yang tidak bekerja.

Dalam penelitian ini
ditemukan bahwa pekerjaan ibu
berhubungan sebab akibat dengan
kejadian pneumonia balita. Ibuyang
bekerja balitanya berisikolebih besar atas
kejadian pneumonia dibandingkan ibu
balita yang tidak bekerja.

Pengetahuan ibu dengan Pneumonia anak balita

Tingkat pengetahuan ibu berdampak besar dalam terjadinya pneumonia balita.Tingginya angka kejadian pneumonia pada balita dikarena pengetahuan ibu yang kurang, misalnya anak-anaknya mendapatkan makanan yang kurang memadai atau jika anaknya sakit terlambat dibawa ke pelayanan kesehatan terdekat, itu semua dikarenakan pengetahuan siibu yang kurang.

Salah satu hasil penelitian menyatakan bahwa ada hubungan yang bermakna pengetahuan ibu dengan kejadian pneumonia pada balita. Ibu balita dengan pengetahuan yang kurang lebih berisiko 1,8 kali untuk terjadi pneumonia dibandingkan ibu balita dengan pengetahuan baik (Sari, 2012). 


\section{Hubungan BBLR dengan Kejadian Pneumonia Balita}

Berat badan lahir menentukan pertumbuhan dan perkembangan fisik dan mental pada masa anak balita.Anak balita dengan berat badan lahir rendah $(<2500$ gram $)$ mempunyai resiko kejadian pneumonia lebih besar dibandingkan dengan balita dengan riwayat berat badan lahir normal (Maryunani dalam Sari, 2012).

Anak balita dengan berat badan lahir rendah akan meningkatkan risiko kesakitan terhadap pneumonia. Hal ini terutama terjadi pada bulan pertama kelahiran sebagai akibat dari pembentukan zat anti kekebalan yang kurang sempurna sehingga lebih mudah terkena penyakit infeksi terutama pneumonia (WHO, 2011).]

Hasil penelitian Lindawati (2010), menyatakan bahwa ada hubungan yang bermakna antara berat badan lahir rendah (BBLR) dengan kejadian pneumonia pada balita.Balita dengan berat badan lahir rendah (BBLR) berpeluang 4,8 kali menderita pneumonia dibanding balita dengan berat badan lahir normal.

\section{Hubungan Status Imunisasi dengan Kejadian Pneumonia Balita}

Imunisasi bertujuan memberikan kekebalan (antibodi) kepada balita dan merupakan salah satu cara menurunkan angka kesakitan terjadinya pneumonia. Penyakit pneumonia lebih mudah menyerang anak yang belum mendapat imunisasi campak dan DPT (Difteri, Pertusis, Tetanus) (Buletin Jendela Epidemiologi, 2010).

Menurut penelitian Hatta dalam Pamungkas (2012), menyatakan bahwa anak balita yang tidak mendapatkan imunisasi campak dan DPT mempunyai risiko 2,307 kali berpeluang menderita pneumonia dibandingkan anak balita yang mendapatkan imunisasi campak dan DPT.

Berdasarkan penelitian Fanada (2012), menyatakan bahwa anak balita yang tidak mendapatkan imunisasi campak dan DPT memiliki risiko 7,6 kali untuk terkena penyakit pneumonia dibandingkan dengan anak balita yang mendapatkan imunisasi campak dan DPT.

Balita yang tidak mendapatkan imunisasi campak besar kemungkinan menderita campak dan DPT yang bisa berpotensi menjadi pneumonia. Jadi, balita yang mendapatkan imunisasi campak tidak menderita pneumonia (Buletin Jendela Epidemiologi, 2010).

Dalam penelitian ini ditemukan bahwa status imunisasi balita yang tidak lengkap (tidak imunisasi campak) berhubungan sebab akibat dengan kejadian pneumonia balita. Asumsi peneliti dalam penelitian ini secara teori di simpulkan bahwa jika anak balita sudah memperoleh imunisasi campak sudah pasti mereka sudah memperoleh imunisasi DPT 1, DPT II dan DPT III maka disimpulkan imunisasinya lengkap. Tetapi jika balita hanya memperoleh imunisasi DPT maka disimpulkan imunisasi tidak lengkap. Balita yang memiliki status imunisasi tidak lengkap berisiko lebih besar menderita pneumonia dibandingkan dengan balita dengan status lengkap.

\section{Hubungan ASI Eksklusif dengan Kejadian Pneumonia Balita}

ASI adalah suatu emulsi lemak dalam larutan protein, laktose dan garam-garam organik yang disekresi oleh kedua kelenjar payudara ibu, sebagai makanan utama bagi bayi dan anakbalita.Pemberian ASI Eksklusif ternyata dapat menurunkan risiko pneumonia pada bayi dan anak balita.Pemberian ASI dapat memberikan 
kekebalan terhadap berbagai macam penyakit karena ASIadalah cairan yang mengandung zat kekebalan tubuh yang dapat melindungi dirinya dari berbagai penyakit infeksi, bakteri, virus, jamur maupun parasit (Nugroho, 2011).

Menurut penelitian Sari (2012), menyatakan bahwa pemberian ASI eksklusif berhubungan dengan kejadian pneumonia, balita yang tidak mendapatkan ASI eksklusif berpeluang 1,924 kali untuk terjadi pneumonia dibandingkan dengan balita yang di beri ASI eksklusif

Balita yang tidak diberi ASI eksklusif besar kemungkinan berpotensi menderita pneumonia dibanding dengan yang tidak diberikan ASI eksklusif. Pemberian ASI dapat memberikan kekebalan terhadap berbagai macam penyakit terutama pneumonia karena ASI mengandung zat kekebalan tubuh yang dapat melindungi dirinya dari berbagai penyakit infeksi, bakteri, virus, jamur maupun parasit (Nugroho, 2011).

Dalam penelitian ini ditemukan bahwa pemberian ASI eksklusif berhubungan sebab akibat dengan kejadian pneumonia balita. Tidak memberikan ASI eksklusif pada balita mempengaruhi kejadian pneumonia lebih besar dibandingkan dengan balita yang diberi ASI eksklusif

\section{Hubungan Kepadatan Hunian dengan Kejadian Pneumonia Balita}

Kepadatan hunian dalam rumah menurut Keputusan Menteri Kesehatan nomor 829/MENKES/SK/VII/1999 tentang persyaratan kesehatan rumah, satu orang minimal menempati luas rumah $8 \mathrm{~m}^{2}$. Tidak dianjurkan digunakan lebih dari 2 orang kecuali anak dibawah umur 5 tahun.Dengan kriteria tersebut diharapkan dapat mencegah penularan penyakit terutama pneumonia (Depkes RI, 2009).

Menurut Penelitian Prameswari, dkk (2011),menyatakan bahwa kepadatan hunian erat kaitannya dengan penularan penyakit. Bila penghuni terlalu padat dan terdapat penghuni yang sakit, maka akan mempercepat transmisi atau penularan penyakit tersebut.

Hasil penelitian lainnya menyatakan bahwa balita yang tinggal dirumah yang padat memiliki risiko 1,3 kali untuk menderita pneumonia dibandingkan denganbalita yang tinggal dirumah yang tidak padat (Pamungkas, 2012).

\section{Hubungan Peran Petugas Kesehatan dengan Kejadian Pneumonia Balita}

Dalam penelitian ini peran petugas kesehatan berhubungan dengan kejadian pneumonia khususnya dibidang promosi kesehatan mengenai masalah pneumonia. Promosi kesehatan ini salah satunya bias dilakukan melalui penyuluhan kesehatan khususnya kepada ibu yang mempunyai balita dan menderita pneumonia.

Salah satu program pemerintah dalam Promosi penanggulangan Pneumonia balita ,mengacu kepada advokasi, bina suasana dan gerakan masyarakat. Tujuan yang diharapkan dari kegiatan promosi pneumonia balita secara umum adalah meninggkatkan pengetahuan, sikap dan tindakan masyarakat dalam upaya penanggulangan pneumonia pada balita. Sasaran promosi didalam P2 ISPA mengacu sasaran primer (ibu balita dan keluarga), sasaran sekunder (petugas kesehatan dan petugas lintas program serta lintas sektor (Depkes RI, 2002).

\section{KESIMPULAN}

1. Masih terdapat masalah pneumonia di wilayah kerja puskesmas Rumbai Kecamatan Rumbai Pesisir Kota Pekanbaru. 
2. Pneumonia balitamasih merupakan masalah kesehatan karena dapat menyebabkan kematian yang cepat bila tidak segera diobati.

3. Terdapat hubungan yang bermakna antara jenis kelamin dengan Kejadian Pneumonia Balita

4. Terdapat hubungan yang bermakna antara pendidikan Ibu dengan Kejadian Pneumonia Balita

5. Terdapat hubungan yang bermakna antara pekerjaan Ibu dengan Kejadian Pneumonia Balita

6. Terdapat hubungan yang bermakna antara pengetahuan Ibu dengan Kejadian Pneumonia Balita

7. Terdapat hubungan yang bermakna antara BBLR dengan Kejadian Pneumonia Balita

8. Terdapat hubungan yang bermakna antara status imunisasi dengan Kejadian Pneumonia Balita

9. Terdapat hubungan yang bermakna antara pemberian ASI eksklusif dengan Kejadian Pneumonia Balita

10.Terdapat hubungan yang bermakna antara kepadatan hunian dengan Kejadian Pneumonia Balita

11.Terdapat hubungan yang bermakna antara peran petugas kesehatan dengan Kejadian Pneumonia Balita

\section{SARAN}

Bagi pihak puskesmas

1. Perlu bekerja sama denganpihak dinas kesehatan untuk mengaktifkan tim promosi kesehatan untuk mengadakan penyuluhan ke posyandu terutama penyuluhan mengenai pneumonia balita

2. Perlu berkoordinasi dengan unit penyuluhan kesehatan masyarakat Dinas Kesehatan Kota dengan melakukan penyuluhan dan promosi kesehatan mengenai penyakit pneumonia
3. Perlu segera mengurangi angka kematian dan kesakitan akibat pneumonia serta menanggulangi masalah pneumonia pada balita

\section{DAFTAR PUSTAKA}

Buletin Jendela Epidemiologi. 2010. Pneumonia Balita. Volume 3, SEPTEMBER 2010. ISSN 20871546 : Jakarta.

Dinkes Prov Riau. 2011. Profil Kesehatan Bidang P4PL, Provinsi Riau..

Dinkes Kota Pekanbaru. 2013. Profil Dinas Kesehatan Kota Pekanbaru Bidang P2 ISPA, Kota Pekanbaru.

Depkes RI, Dirjen P2PL. 2009. Pedoman Pengendalian Penyakit Infeksi Saluran. Pernapasan akut : Jakarta.

Fanada, Mery (2012). Faktor-faktor yang Berhubungan dengan Kejadian Penyakit Pneumonia pada Balita di Wilayah Kerja Puskesmas Kenten Palembang Tahun 2012 : Badan Diklat Provinsi Sumatera Selatan

Kemenkes, RI. 2010. Klasifikasi Status Gizi Pada Anak Balita :Jakarta. Kemenkes, 2010. Pneumonia Pembunuh Balita No. 1 Di Dunia :Jakarta.

Lindawati.(2010).Faktor Risiko yang Berhubungan dengan Insiden Pneumonia Pada Anak Balita Di Wilayah Kerja Puskesmas Duyun Kabupaten Siak Tahun 2010. Diterbitkan di Pekanbaru : Stikes Hang Tuah Pekanbaru.

Nugroho, T. 2011. Asidan Tumor Payudara. Yogyakarta: Nuhamedika

Pamungkas, Dian Rahayu, 2012. Analisis Faktor Risiko Pneumonia pada Anak Balita di 4 Provinsi Di 
Wilayah Indonesia Timur. Diterbitkan : FKM UI. Depok.

Prameswari, dkk. 2011. Hubungan antara Sanitasi Rumah dan Perilaku dengan Kejadian Pneumonia Balita. Kesmas 6(2) (2011) 71-78. Januari 2011. ISSN 1858-1196.

Sari, R. (2012).Faktor-Faktor yang Berhubungan dengan Kejadian
Pneumonia Pada Balita Di Wilayah Kerja Puskesmas Garuda Kecamatan Marpoyan Damai Kota Pekanbaru Tahun 2012. Diterbitkan di Pekanbaru : Stikes Hang Tuah Pekanbaru.

WHO 2011.Global Action Plan for the Prevention and Control of Pneumonia (GAPP). Genewa: WHO Press. 